Check for updates

Cite this: RSC Adv., 2017, 7, 40444

Received 4th May 2017

Accepted 8th August 2017

DOI: $10.1039 / c 7 r a 05007 k$

rsc.li/rsc-advances

\section{Mn-Fe bi-metal oxides in situ created on metal wire mesh as monolith catalysts for selective catalytic reduction of $\mathrm{NO}$ with $\mathrm{NH}_{3}^{\dagger}$}

\author{
Jie Liu, Lin Kang, Hongrui Li, Phornphimon Maitarad, Jianping Zhang, Liyi Shi \\ and Dengsong Zhang $\mathbb{D D}^{*}$
}

In this work, we use an Fe wire mesh to provide homogeneous nucleation sites to support a continuous in situ growth of $\mathrm{Mn}$-Fe bi-metal oxides as monolith catalysts for selective catalytic reduction of $\mathrm{NO}$ with $\mathrm{NH}_{3}$. The strategy of a "twin iron source" makes the Mn-Fe seeds easily grow on the Fe wire mesh through the surface Fe metal sites rather than free growth. The Fe wire mesh exhibited excellent affinity properties with $\mathrm{Mn}-\mathrm{Fe}$ hydroxides precursor. Through the calcination treatment, a spinel structure of $\mathrm{Mn}-\mathrm{Fe}$ bi-metal oxides coated monolithic catalyst was prepared and used for denitrification. By adjusting the ratio of the $\mathrm{Mn}-\mathrm{Fe}$ precursors, we obtained $\mathrm{Mn}-\mathrm{Fe}$ bi-metal oxides with various morphologies coated on the surface of Fe wire mesh. Impressively, the cube-like $\mathrm{Mn}$-Fe bi-metal oxides structure on the Fe wire mesh as monolith catalysts exhibited high De- $\mathrm{NO}_{x}$ performance, catalytic activity, stability, $\mathrm{H}_{2} \mathrm{O}$ tolerance, $\mathrm{K}^{+}$poisoning resistance and regeneration performance. The results showed that the spinel structure of $\mathrm{Mn}-\mathrm{Fe}$ bi-metal oxides in the coating layer was the critical factor for enhanced adsorption behaviours and reducibilities, which promoted selective catalytic reduction of $\mathrm{NO}$ with $\mathrm{NH}_{3}$. The good adhesion between the $\mathrm{Mn}-\mathrm{Fe}$ spinel and Fe wire mesh contributed to the super stability and the strong adsorption properties of $\mathrm{NH}_{3}$, which made it dominant in the $\mathrm{NH}_{3}$ adsorption process competing with water. The obtained monolith catalysts showed good resistances to $\mathrm{K}^{+}$poisoning and good regeneration performance, which can be attributed to the structural stability of $\mathrm{Mn}-$ Fe spinel and strong synergistic effect between the support and active species. This new kind of monolithic catalyst prepared by an in situ technique can be used as a potential substitute for vanadium based ceramic catalysts.

\section{Introduction}

Nitrogen oxides $\left(\mathrm{NO}_{x}\right)$ are a major kind of pollutant emitted from stationary sources that can lead to various environmental problems, such as acid rain, greenhouse effects and photochemical smog. ${ }^{1-4}$ The selective catalytic reduction of NO with $\mathrm{NH}_{3}$ ( $\mathrm{NH}_{3}$-SCR) is an efficient and economic commercial technique for denitrification $\left(\right.$ De- $\left.\mathrm{NO}_{x}\right){ }^{5-7}$ The V-based catalysts are commonly used to eliminate $\mathrm{NO}_{x}$ in stationary sources, and they exhibit an excellent catalytic activity and selectivity. ${ }^{8-10}$ However, the high and narrow operation temperature window (300-400 ${ }^{\circ} \mathrm{C}$ ), susceptibility to alkali poisoning, as well as the volatility and toxicity of $\mathrm{VO}_{x}$ inhibit their enormous applications. ${ }^{\mathbf{1 1 - 1 5}}$

Recently, manganese based catalysts have stimulated great interest by virtue of their excellent oxidation-reduction properties, environmentally friendly features and low-temperature

Research Center of Nano Science and Technology, Shanghai University, Shanghai 200444, China. E-mail: dszhang@shu.edu.cn; Tel: +86-21-66137152

$\dagger$ Electronic supplementary information (ESI) available: TGA curves, $\mathrm{N}_{2}$ selectivity, and catalytic experimental results of the catalysts. See DOI: 10.1039/c7ra05007k activities, which render their great potential in $\mathrm{NH}_{3}$-SCR application. ${ }^{\mathbf{1 6 - 2 7}}$ Chen et al. investigated the $\mathrm{Cr}-\mathrm{Mn}$ mixed-oxide catalysts and achieved $98.5 \% \mathrm{NO}_{x}$ conversion at $120{ }^{\circ} \mathrm{C}$, which can be attributed to the strong interaction between the active components in $\mathrm{Cr}_{1.5} \mathrm{MnO}_{4}$ spinel structure. ${ }^{23}$ Zhan et al. prepared a kind of $\mathrm{Mn}-\mathrm{FeO}_{x}$ hexagonal microsheet for low temperature $\mathrm{NH}_{3}$-SCR. It was found that this catalyst exhibited above $90 \% \mathrm{NO}_{x}$ conversion between 150 and $300{ }^{\circ} \mathrm{C}$ and excellent $\mathrm{H}_{2} \mathrm{O}$ resistance, as well as thermal stability. ${ }^{28} \mathrm{Cui}$ et al. also prepared $\mathrm{Mn}-\mathrm{Ce}-\mathrm{Ni} / \mathrm{TiO}_{2}$ catalyst for low temperature $\mathrm{NH}_{3}-\mathrm{SCR}$ of NO by introducing a co-precipitation method, which exhibited a $88 \%$ NO conversion in the presence of alkali metals between 150 and $300{ }^{\circ} \mathrm{C}(\mathrm{K} / \mathrm{Mn}=0.5) .{ }^{29}$ In our previous studies, the $\mathrm{Mn}_{x} \mathrm{Co}_{3-x} \mathrm{O}_{4}$ nanocage catalyst was developed for the $\mathrm{NO}_{x}$ removal and the catalyst exhibited a wide operation window from $120{ }^{\circ} \mathrm{C}$ to $350{ }^{\circ} \mathrm{C} .{ }^{18}$ The $\mathrm{MnO}_{x}-\mathrm{FeO}_{y}$ nanocage achieved $87.8 \% \mathrm{NO}_{x}$ conversion at $80{ }^{\circ} \mathrm{C} .{ }^{30}$ However, the catalytic performance of the above manganese based catalysts for the practical De-NO $\mathrm{N}_{x}$ application is still far from satisfactory. This can be ascribed to the following factors. Generally, the powdered catalysts should be coated on the surface of supports to achieve high specific surface area and low pressure drop in 
industrial utilization. However, the commonly used ceramic honeycomb supports suffer from the poor adhesion stability between the powdered catalysts and the support, which inevitably leading to the leakage of active species on the surface during the catalytic process and the deactivation of the monolithic catalyst. ${ }^{31,32}$ In addition, the ceramic supports also possess certain defects of poor interphase heat transfer ability, low mechanical strength and random distribution of catalyst powder. ${ }^{33,34}$

To overcome those disadvantages, some metal supported monolith catalysts have been designed and developed, which have such advantages as strong mechanical stability, plasticity, thermal conductivity and mass transfer ability. ${ }^{26,27}$ It is favorable for the catalytic processes and suitable for practical applications. ${ }^{35-41}$ In order to construct a stable bi-metal oxides layer in the support of wire mesh, an in situ growth technique has been effectively introduced. For this method, heterogeneous nucleation and following crystallite intergrowth are indispensable. Therefore, the strategy of "twin metal source" will be a viable solution. ${ }^{42}$ Good affinity between the same metal precursor and the wire mesh makes the seed crystals easily grow on metal wire mesh through the surface of metal sites rather than free growth.

Herein, we developed a "twin iron source" strategy for the in situ construction of $\mathrm{Mn}-\mathrm{Fe}$ oxides on Fe wire mesh and the formation route of the Mn-Fe oxides was shown in Fig. 1. First, Fe wire meshes that removed surface oxide were immersed into the $\mathrm{Mn}-\mathrm{Fe}$ precursor solution for hydrothermal reaction at $90{ }^{\circ} \mathrm{C}$ for $6 \mathrm{~h}$. In the course of the decomposition of urea, the $\mathrm{Mn}-\mathrm{Fe}$ species were heterogeneous on the surface of the Fe wire mesh by the iron sites and then form the seed crystals. The subsequent growth of seed crystals could lead to form different morphologies and uniformity distribution $\mathrm{Mn}-\mathrm{Fe}$ bi-metal hydroxides particles by adjusting the ratio of the precursors. Finally, stable and uniform distribution Mn-Fe bi-metal oxides formed on the surface of the Fe wire mesh after the calcination process. This in situ coating technology not only realized the stable decoration of $\mathrm{Mn}-\mathrm{Fe}$ hydroxides precursors on the surface of the Fe wire mesh, but also ensured the uniform dispersion of the active species. The formation of the bi-metal oxide layer mainly contained spinel structure of $\mathrm{Mn}-\mathrm{Fe}$ bimetal oxides species, which showed excellent catalytic activity, stability, $\mathrm{H}_{2} \mathrm{O}$ tolerance, $\mathrm{K}^{+}$poisoning resistance and regeneration performance.

\section{Experimental section}

\section{Catalysts preparation}

Commercial iron meshes and titanium meshes with the mesh pore size of $0.180 \mathrm{~mm}$ were provided by Shanghai Fine Sieving Filtrating Equipment Co., Ltd (China). While nickel foam and copper foam with the porosity of $95-98 \%$ were supplied by Ailantian Advanced Technology Materials Co. Ltd (Dalian, China). These metal substrates were separated into desired scales and sizes $(3 \mathrm{~cm} \times 10 \mathrm{~cm})$, and then pretreated with $1 \mathrm{M}$ $\mathrm{HCl}$ to remove the surface oxides. Afterwards, the metal substrates were washed with deionized water to eliminate residual acids.

The $\mathrm{Mn}-\mathrm{Fe}(x: y) @ \mathrm{Fe}$ wire mesh monolithic catalysts were fabricated using a water bath deposition method with urea. The

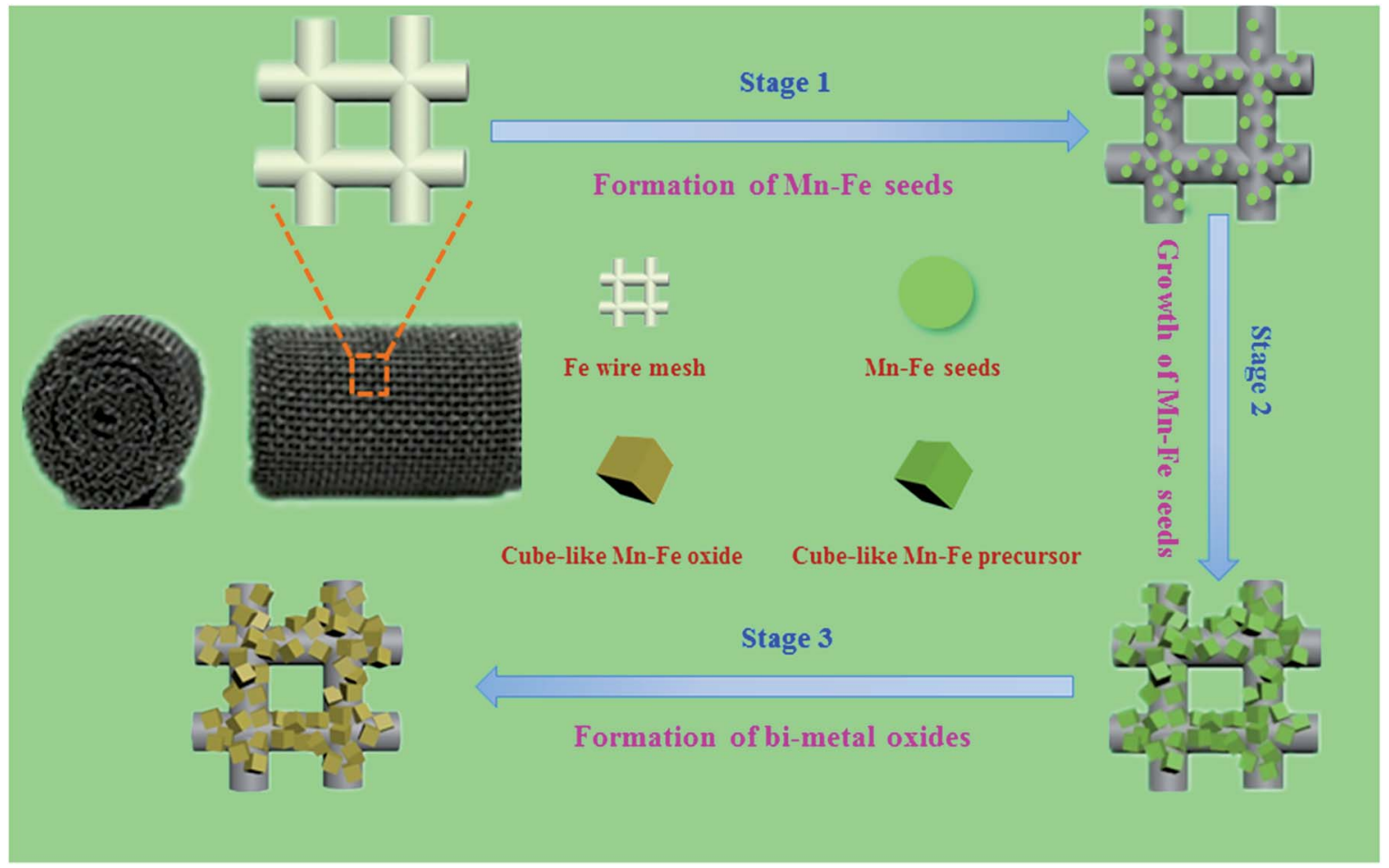

Fig. 1 Schematic illustration of the fabrication of $\mathrm{Mn}-\mathrm{Fe}(1: 1)$ aFe WM monolithic catalyst. 
$x: y$ was the molar ratio of manganese and iron. A typical example of catalyst preparation was presented as following steps. $0.005 \mathrm{~mol} \mathrm{Mn}(\mathrm{Ac})_{2} \cdot 4 \mathrm{H}_{2} \mathrm{O}, 0.005 \mathrm{~mol} \mathrm{Fe}\left(\mathrm{NO}_{3}\right)_{3} \cdot 9 \mathrm{H}_{2} \mathrm{O}$ and $0.03 \mathrm{~mol} \mathrm{CO}\left(\mathrm{NH}_{2}\right)_{2}$ were dissolved in $70 \mathrm{ml}$ of deionized water with continuous stirring. After completely dissolved, the Fe wire mesh $(3 \mathrm{~cm} \times 10 \mathrm{~cm})$ was immersed into the solution and then transferred the reaction system to a $100 \mathrm{ml}$ Teflon-lined stainless steel autoclave and reacted at $90{ }^{\circ} \mathrm{C}$ for $6 \mathrm{~h}$. After the reaction, the autoclave was cooled at room temperature. The product was washed by deionized water for several times and dried at $80{ }^{\circ} \mathrm{C}$. The in situ coated $\mathrm{Mn}-\mathrm{Fe}$ bi-metal oxides wire mesh precursor was calcined at $500{ }^{\circ} \mathrm{C}$ for $4 \mathrm{~h}$ in muffle furnace with a heating rate of $2{ }^{\circ} \mathrm{C} \mathrm{min}^{-1}$. Finally, we got $\mathrm{Mn}-\mathrm{Fe}(1: 1)$ @Fe wire mesh (Mn-Fe(1:1)@Fe WM) monolithic catalyst. As contrast, $\mathrm{Mn}-\mathrm{Fe}(2: 1) @ \mathrm{Fe}$ wire mesh (Mn-Fe(2:1)@Fe WM), $\mathrm{Mn}-\mathrm{Fe}(1: 2) @ \mathrm{Fe}$ wire mesh (Mn-Fe(1:2)@Fe WM), Mn@Fe wire mesh (Mn@Fe WM), Fe@Fe wire mesh (Mn@Fe WM), Mn$\mathrm{Fe}(1: 1) @$ honeycomb ceramics (Mn-Fe(1 : 1)@HCCS) and Mn$\mathrm{Fe}(1: 1) @ o t h e r$ common metal substrates $(\mathrm{Cu}$ wire mesh, $\mathrm{Ti}$ wire mesh, $\mathrm{Ni}$ form and $\mathrm{Cu}$ form) monolithic catalysts were prepared using the similar conditions.

\section{Catalyst characterization}

The morphology and structure of the nanocatalysts were characterized by a scanning electron microscope (SEM, JEOL JEM200CX). The X-ray diffraction (XRD) patterns were recorded on a Rigaku D/MAS-RB X-ray diffract meter, using $\mathrm{Cu}-\mathrm{K} \alpha$ radiation operated at $40 \mathrm{kV}$ and $40 \mathrm{~mA}$. Thermo gravimetric analysis (TGA) was performed on a NETZSCH STA 449 F1. The temperature was increased from 100 to $600{ }^{\circ} \mathrm{C}$ with a ramping rate of $10{ }^{\circ} \mathrm{C} \min ^{-1}$ in $\mathrm{N}_{2} \cdot \mathrm{H}_{2}$ temperature-programmed reduction $\left(\mathrm{H}_{2}\right.$ TPR) was carried out on a Tianjin XQ tp5080 autoadsorption apparatus. In a typical run, $500 \mathrm{mg}$ of monolithic catalyst was used and heated to $300{ }^{\circ} \mathrm{C}$ under $\mathrm{N}_{2}\left(30 \mathrm{ml} \mathrm{min}^{-1}\right)$ to remove any adsorbed species for $30 \mathrm{~min}$ with a temperature rise rate of $10{ }^{\circ} \mathrm{C} \mathrm{min}^{-1}$. After cooling down to $25{ }^{\circ} \mathrm{C}$, the catalyst was

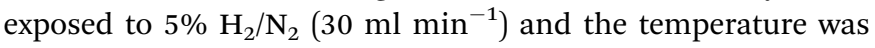
subsequently raised from 25 to $900{ }^{\circ} \mathrm{C}$ with a ramping rate of $10{ }^{\circ} \mathrm{C} \mathrm{min}{ }^{-1} . \mathrm{NH}_{3}$ temperature-programmed desorption $\left(\mathrm{NH}_{3}-\right.$ TPD) was carried out on a Tianjin XQ tp5080 autoadsorption apparatus. In a typical run, $1000 \mathrm{mg}$ of monolithic catalyst was used and heated to $300{ }^{\circ} \mathrm{C}$ under $\mathrm{He}\left(30 \mathrm{ml} \mathrm{min}^{-1}\right)$ to remove any adsorbed species for $30 \mathrm{~min}$ with a rising rate of $10{ }^{\circ} \mathrm{C}$ $\min ^{-1}$. After cooling down to $100{ }^{\circ} \mathrm{C}$, the catalyst was exposed to $500 \mathrm{ppm} \mathrm{NH}_{3}\left(30 \mathrm{ml} \mathrm{min}^{-1}\right)$ for $1 \mathrm{~h}$, followed by He purging for $0.5 \mathrm{~h}$ to remove physisorbed $\mathrm{NH}_{3}$, and the temperature was subsequently raised from 100 to $800{ }^{\circ} \mathrm{C}$ with a ramping rate of $10{ }^{\circ} \mathrm{C} \min ^{-1}$.

\section{Catalyst performance tests}

The $\mathrm{NH}_{3}$-SCR activity was tested in a fixed-bed quartz reactor ( $8 \mathrm{~mm}$ i.d.) using $3 \mathrm{~cm} \times 10 \mathrm{~cm}$ of the catalysts. The feed gas mixture in a $\mathrm{N}_{2}$ stream contained $500 \mathrm{ppm}$ of NO, $500 \mathrm{ppm}$ of $\mathrm{NH}_{3}$, and 3 vol\% $\mathrm{O}_{2}$. The total flow rate of feed gases was $260 \mathrm{ml} \mathrm{min}{ }^{-1}$ with the gas hourly space velocity (GHSV) of $20000 \mathrm{~h}^{-1}$. The concentration of NO in the inlet and outlet gases was got continuously by a $4000 \mathrm{VM}$ analyzer. All the data points were collected in a steady state for $15 \mathrm{~min}$ at the corresponding temperature. NO conversion was calculated according to the following equation:

$$
\text { NO conversion }(\%)=\frac{[\mathrm{NO}]_{\text {in }}-[\mathrm{NO}]_{\text {out }}}{[\mathrm{NO}]_{\text {in }}} 100 \%
$$

$$
\times\left(1-\frac{2\left[\mathrm{~N}_{2} \mathrm{O}\right]_{\text {out }}}{[\mathrm{NO}]_{\text {in }}+\left[\mathrm{NH}_{3}\right]_{\text {in }}-[\mathrm{NO}]_{\text {out }}-\left[\mathrm{NH}_{3}\right]_{\text {out }}}\right) 100 \%
$$

where the $[\mathrm{NO}]_{\text {in }},[\mathrm{NO}]_{\text {out }},\left[\mathrm{N}_{2} \mathrm{O}\right]_{\text {out }}$ and $\left[\mathrm{NH}_{3}\right]_{\text {in }}$ indicate the inlet and outlet concentration at steady-state, respectively.

In the water resistance test, the water was pumped into the vaporization chamber before the reactor with a controlled flow water pump. The water was heated and vaporized at $200{ }^{\circ} \mathrm{C}$ and then was passed through the reactor. In the $\mathrm{K}^{+}$resistance test, the catalyst was immersed in potassium nitrate solution containing $\mathrm{K}^{+}$with $0.3 \mathrm{wt} \%$ of the total mass of the monolith catalyst. Then, the solution was steamed to dry and the sample was dried at $80{ }^{\circ} \mathrm{C}$ and calcined for $2 \mathrm{~h}$ at $500{ }^{\circ} \mathrm{C}$. The catalysts after poisoning were named K-poisoning-Mn-Fe(1 : 1)@Fe WM, K-poisoning-Mn-Fe(1:2)@Fe WM and K-poisoning-Mn$\mathrm{Fe}(2: 1) @ \mathrm{Fe} W M$, respectively. For the regeneration, the corresponding catalyst was soaked in a $100 \mathrm{ml}$ water at $60{ }^{\circ} \mathrm{C}$ for 30 minutes and repeated three times.

\section{Results and discussion}

\section{Morphology evolution of Mn-Fe@Fe wire mesh catalysts}

In order to confirm the composition of different structures and understand the spatial distribution of the corresponding elements, SEM and EDS mapping analysis were performed to probe surface morphologies of three monolithic catalysts and the results were shown in Fig. 2 and S1. $\dagger$ Through SEM observation, we found that $\mathrm{Mn}-\mathrm{Fe}(1: 1) @ \mathrm{Fe}$ WM monolithic catalyst was covered with cube-like bi-metal layer. The surface morphologies of $\mathrm{Mn}-\mathrm{Fe}(2: 1)$ and $\mathrm{Mn}-\mathrm{Fe}(1: 2)$ bi-metal oxides were mainly of block-like shape. The morphologies of these particles on the surface of these monolithic catalysts were obviously different due to the different ratio of the manganese and iron precursors. According to the EDS mapping images of $\mathrm{Mn}-\mathrm{Fe}(1: 1) @ \mathrm{Fe} \mathrm{WM}$, the cubic structure in wire mesh surface were composed of rich $\mathrm{Mn}$ and Fe elements, which were highly dispersed and uniform. At the same time, in the EDS mapping images of $\mathrm{Mn}-\mathrm{Fe}(2: 1) @ \mathrm{Fe} \mathrm{WM}$, it also displayed a highly dispersed and uniform distribution of $\mathrm{Mn}$ and Fe elements in the block-like shape structure. But there were more $\mathrm{Mn}$ elements than Fe elements. It was worth noting that there was almost no Mn species in the small globular morphology of Mn$\mathrm{Fe}(1: 2) @ \mathrm{Fe} W \mathrm{~W}$, which indicated that the deposition of Mn species was very little in this feed ratio of $\mathrm{Mn}$ and Fe species. The reason for this proportion of different elements was the different ratio of the manganese and iron precursors.

In order to analyse the crystal structure of $\mathrm{Mn}-\mathrm{Fe}$ precursor and bi-metallic oxides on three monolithic catalysts, we 

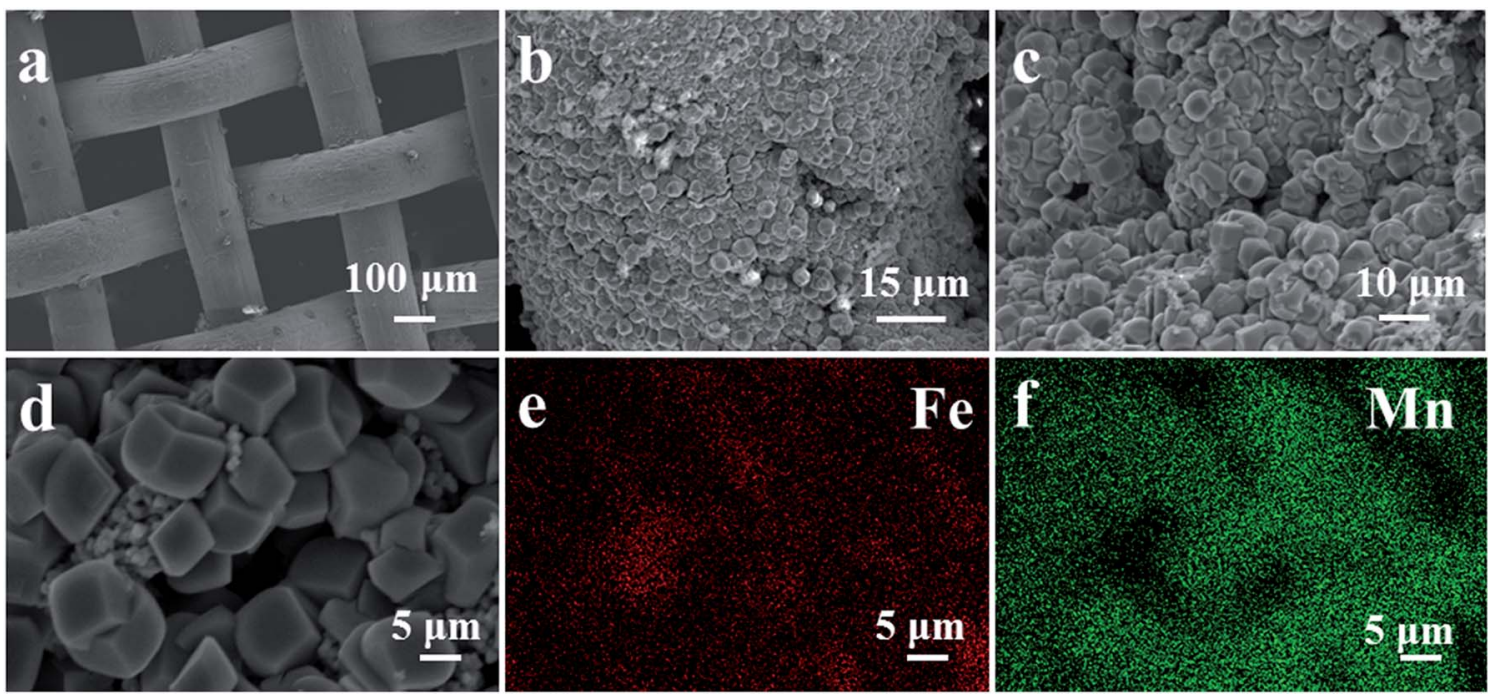

Fig. 2 (a-c) SEM images of Fe wire mesh and surface structure of Mn-Fe(1:1)@Fe WM monolithic catalyst; (d-f) SEM images and elemental mappings results of $\mathrm{Mn}-\mathrm{Fe}(1: 1)$ aFe WM monolithic catalyst.

conducted XRD tests. To reduce the impact of the Fe substrate, we obtained the precursor and bi-metal oxide powder on the surface of the wire mesh. In the XRD patterns of Mn-Fe(1:1) precursors (Fig. S2 $\dagger$ ), we found that the precursor mainly contains $\mathrm{Mn}(\mathrm{OH})_{2}$ (JCPDs: 12-0696), $\mathrm{Fe}_{2} \mathrm{O}_{3} \cdot 1.2 \mathrm{H}_{2} \mathrm{O}$ (JCPDs: 221117) and $\mathrm{Fe}_{2} \mathrm{O}_{3}$ (JCPDs: 04-0755). The material composition of hydroxides provided an important material basis for the formation of Mn-Fe bi-metal. In the XRD patterns of bi-metal oxide (Fig. 3), it could be observed two crystalline phases. The peaks located at $24.2^{\circ}, 33.3^{\circ}, 41.0^{\circ}, 49.5^{\circ}, 53.7^{\circ}, 64.1^{\circ}$ and $72.1^{\circ}$ correspond to the spinel structure of $\left(\mathrm{Mn}_{0.37} \mathrm{Fe}_{0.63}\right)_{2} \mathrm{O}_{3}$ (JCPDs: 71-0637). The peaks located at $18.2^{\circ}, 30.3^{\circ}, 35.7^{\circ}, 37.2^{\circ}, 43.3^{\circ}$, $53.7^{\circ}, 57.2^{\circ}, 62.9^{\circ}$ and $72.1^{\circ}$ corresponding to the $\mathrm{Fe}_{3} \mathrm{O}_{4}$ (JCPDs: 75-0033). It was visually observable that there were similar characteristic peaks in Mn-Fe(1:1)@Fe WM, Mn-Fe(2:1)@Fe $\mathrm{WM}$ and $\mathrm{Mn}-\mathrm{Fe}(1: 2) @ \mathrm{Fe} \mathrm{WM}$ catalysts, indicating the similar

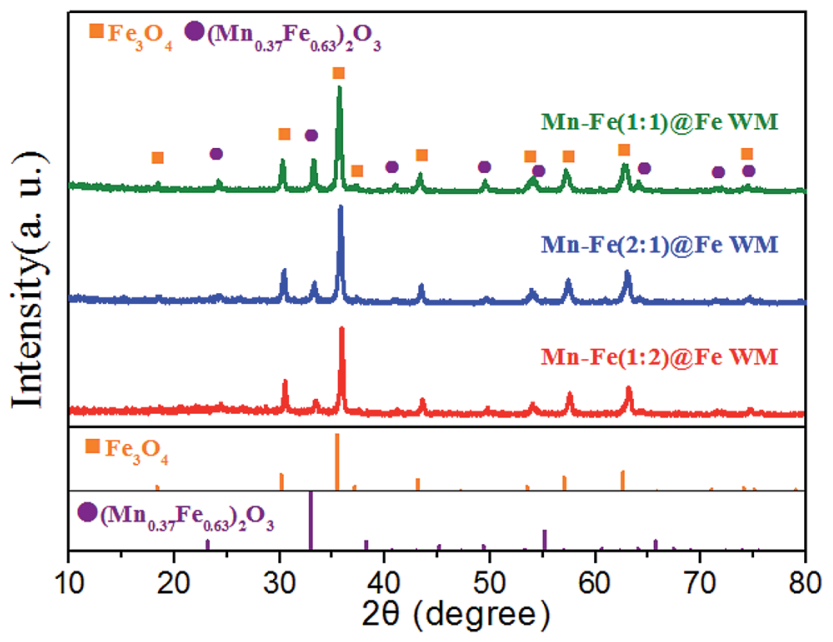

Fig. 3 XRD patterns of the powder obtained from the Mn-FeaFe WM catalysts. features of composition and structure in these catalysts. It is worth mentioning that the intensity of $\left(\mathrm{Mn}_{0.37} \mathrm{Fe}_{0.63}\right)_{2} \mathrm{O}_{3}$ was the highest in $\mathrm{Mn}-\mathrm{Fe}(1: 1) @ \mathrm{Fe}$ mesh and the lowest in $\mathrm{Mn}-$ $\mathrm{Fe}(1: 2) @ \mathrm{Fe}$ mesh, which coincided with the activity curve trend. It indicated that the ratio of $1: 1$ of $\mathrm{Mn}$ and Fe was more favourable for the formation of $\left(\mathrm{Mn}_{0.37} \mathrm{Fe}_{0.63}\right)_{2} \mathrm{O}_{3}$ and participated in the $\mathrm{NH}_{3}$-SCR reaction.

\section{Surface properties of $\mathrm{Mn}-\mathrm{Fe} @ \mathrm{Fe}$ wire mesh catalysts}

The TGA was used to analyse the thermal decomposition behaviour of the monolith precursors through hydrothermal reaction. The TGA results showed that the monolith precursors decomposed completely at about $450{ }^{\circ} \mathrm{C}$, which gave us a guideline for the calcination temperature of these monolith precursors (Fig. S3†). Therefore, it could be ensured that the precursors were completely decomposed at $500{ }^{\circ} \mathrm{C}$. In addition, the weight loss ratio of $\mathrm{Mn}-\mathrm{Fe}(1: 1) @ \mathrm{Fe}$ was the highest, reaching $-2.72 \%$. It suggested that this proportion of $\mathrm{Mn}-\mathrm{Fe}$ species was the most conducive to the growth of bi-metallic oxide precursor on the Fe wire mesh.

\section{$\mathrm{NH}_{3}$-TPD adsorption properties}

The absorption of $\mathrm{NH}_{3}$ onto the catalyst plays a significant role in the SCR reaction. ${ }^{29,43}$ The adsorption behaviour of ammonia on Fe wire mesh monolith catalysts were studied by $\mathrm{NH}_{3}$-TPD method as shown in Fig. 4. It could be observed in Fig. 4 that the three kinds of monolith catalysts showed similar ammonia adsorption sites. The desorption peaks before $250{ }^{\circ} \mathrm{C}$ were attributed to the weak adsorption of ammonia in the Brønsted acid sites. At the same time, desorption peaks from 350 to $550{ }^{\circ} \mathrm{C}$ were ascribed to the strong adsorption of ammonia in the Lewis acid sites. The area of desorption peaks in the $\mathrm{NH}_{3}-$ TPD profile could reflect the amounts of $\mathrm{NH}_{3}$ species coordinated to the surface acid sites. ${ }^{44} \mathrm{Mn}-\mathrm{Fe}(1: 1) @ \mathrm{Fe}$ and Mn$\mathrm{Fe}(1: 2) @ F e$ WM monolith catalysts showed the best and least 


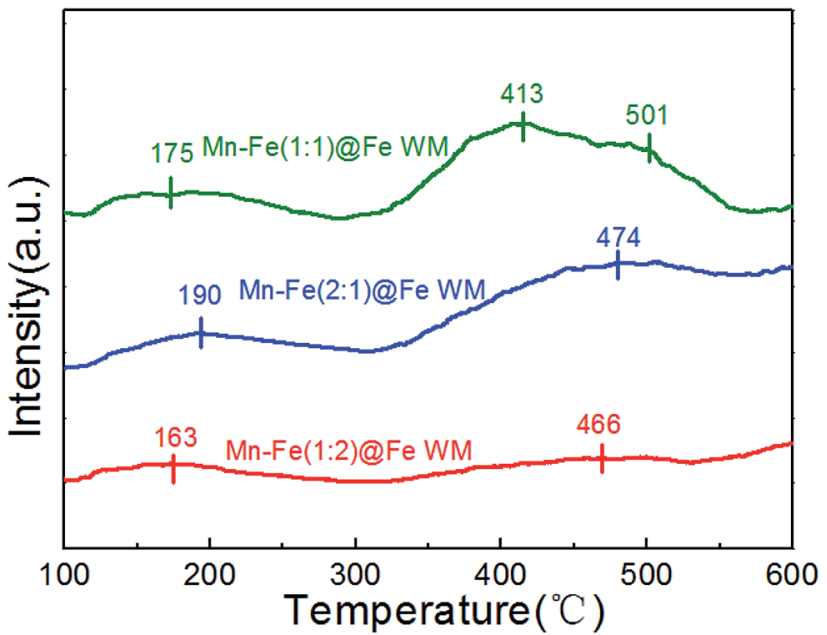

Fig. $4 \mathrm{NH}_{3}$-TPD profiles of $\mathrm{Mn}-\mathrm{Fe}(\mathrm{Fe}$ WM catalysts.

amount of ammonia desorption. This trend was positively correlated with the intensity of the peak of $\left(\mathrm{Mn}_{0.37} \mathrm{Fe}_{0.63}\right)_{2} \mathrm{O}_{3}$, which indicated that the main adsorption site of the monolith catalyst was $\left(\mathrm{Mn}_{0.37} \mathrm{Fe}_{0.63}\right)_{2} \mathrm{O}_{3}$ site. It confirmed the superior ammonia storage capacity onto the surfaces of $\mathrm{Mn}-\mathrm{Fe}(1: 1) @ \mathrm{Fe}$ WM, which was favorable for the $\mathrm{NH}_{3}$-SCR reaction.

The adsorption behaviours of ammonia on monolith catalysts with other metal supports were different due to the unfavorable formation of active sites on the supports (Fig. S4†). It could be observed that there was hardly any $\mathrm{NH}_{3}$ desorption peak in $\mathrm{Mn}-\mathrm{Fe}(1: 1) @ \mathrm{Cu} \mathrm{WM}$ and $\mathrm{Mn}-\mathrm{Fe}(1: 1) @ T i$ WM catalysts, which was attributed to the unfavorable growth of $\mathrm{Mn}-\mathrm{Fe}$ species on other metal supports.

\section{$\mathrm{H}_{2}$-TPR reduction performances}

The redox properties of the catalysts were crucial to the $\mathrm{NH}_{3}$ $\mathrm{SCR}$ reaction. Therefore, we applied $\mathrm{H}_{2}$-TPR to understand the redox process of $\mathrm{Mn}-\mathrm{Fe} @ \mathrm{Fe} \mathrm{WM}$ monolith catalysts, which were shown in Fig. 5 . These reduction steps on the $\mathrm{Mn}-\mathrm{Fe}(1: 1)$ (a)e WM corresponded to the peaks at $386{ }^{\circ} \mathrm{C}, 433{ }^{\circ} \mathrm{C}$, and $680^{\circ} \mathrm{C}$. While the $\mathrm{Mn}-\mathrm{Fe}(2: 1) @ \mathrm{Fe} \mathrm{WM}$ resulted in the peaks at $352{ }^{\circ} \mathrm{C}, 430{ }^{\circ} \mathrm{C}$ and $649{ }^{\circ} \mathrm{C}$. This represented the reduced of $\left(\mathrm{Mn}_{0.37} \mathrm{Fe}_{0.63}\right)_{2} \mathrm{O}_{3}, \mathrm{Fe}_{3} \mathrm{O}_{4} \rightarrow \mathrm{FeO}$, as well as the further reduced of low state of $\mathrm{Mn}$ and Fe species. ${ }^{45-47}$ It was worth noting that the Mn-Fe(1:2)@Fe WM only contained two peaks at $432{ }^{\circ} \mathrm{C}$ and $624{ }^{\circ} \mathrm{C}$, which mainly corresponded to $\mathrm{Fe}_{3} \mathrm{O}_{4} \rightarrow \mathrm{FeO}$ and $\mathrm{FeO} \rightarrow \mathrm{Fe}$. It was mainly due to the catalyst contains too little Mn species. The redox peak of $\left(\mathrm{Mn}_{0.37} \mathrm{Fe}_{0.63}\right)_{2} \mathrm{O}_{3}$ crystalline was highest in $\mathrm{Mn}-\mathrm{Fe}(1: 1) @ \mathrm{Fe}$ WM. It could be demonstrated that the ratio of $1: 1$ of $\mathrm{Mn}$ and Fe lead to more reducible species and thereafter enrich the redox cycle in the catalytic process. For comparison, the $\mathrm{H}_{2}$-TPR of $\mathrm{Mn}-\mathrm{Fe} @ \mathrm{Cu} \mathrm{WM}, \mathrm{Mn}-\mathrm{Fe} @ \mathrm{Ti} \mathrm{WM}$, $\mathrm{Cu} \mathrm{WM}$ and Ti WM were carried out (Fig. S5 $\dagger$ ). The peaks at 286 and $640{ }^{\circ} \mathrm{C}$ represented the reduction of $\mathrm{CuO} \rightarrow \mathrm{Cu}_{2} \mathrm{O}$ and $\mathrm{Cu}_{2} \mathrm{O} \rightarrow \mathrm{Cu}$. The peak at $327^{\circ} \mathrm{C}$ was attributed to the reduction of $\mathrm{TiO}_{2} \rightarrow$ Ti. It was interested that the $\mathrm{Mn}-\mathrm{Fe} @ \mathrm{Cu} \mathrm{WM}, \mathrm{Mn}-$ Fe@Ti WM showed the similar peak positions and types with

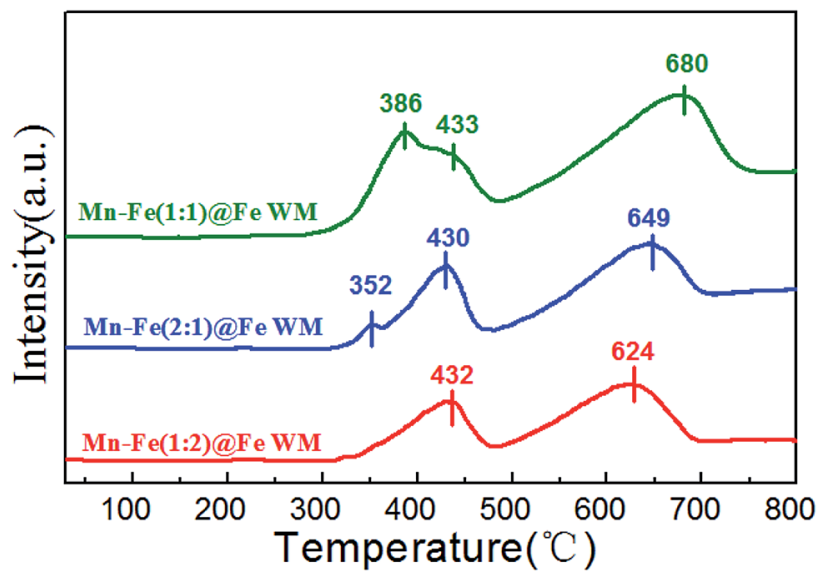

Fig. $5 \mathrm{H}_{2}$-TPR profiles of Mn-FeaFe WM catalysts.

$\mathrm{Cu} \mathrm{WM}$ and Ti WM, respectively. It confirms the unfavorable growth of Mn-Fe species on other metal supports.

\section{Catalytic performance}

The $\mathrm{NH}_{3}$-SCR reaction over Mn-Fe@Fe WM monolith catalysts were performed during $100-400{ }^{\circ} \mathrm{C}$ as showed in Fig. 6 . The Mn$\mathrm{Fe}(1: 1) @ \mathrm{Fe}$ WM monolith catalyst showed the lowest activation temperature and highest NO conversion for a whole temperature window. The NO conversion was over $90 \%$ at $175-$ $300{ }^{\circ} \mathrm{C}$ for $\mathrm{Mn}-\mathrm{Fe}(1: 1) @ \mathrm{Fe} \mathrm{WM}$ with a high $\mathrm{N}_{2}$ selectivity (Fig. S6 $†$ ). Especially, the $\mathrm{N}_{2}$ selectivity of $\mathrm{Mn}-\mathrm{Fe}(1: 1) @ \mathrm{Fe} \mathrm{WM}$ was as high as more than $75 \%$ until $300{ }^{\circ} \mathrm{C}$. It showed Mn$\mathrm{Fe}(1: 1) @ \mathrm{Fe} W \mathrm{~W}$ had good $\mathrm{N}_{2}$ selectivity. The excellent catalytic activity was attributed to the formation of $\left(\mathrm{Mn}_{0.37} \mathrm{Fe}_{0.63}\right)_{2} \mathrm{O}_{3}$ in the cubic structure in the coating layer, which acted as the main active species for the $\mathrm{NH}_{3}$-SCR reaction. The Mn-Fe(2:1)@Fe WM showed $10 \%$ lower activity than Mn-Fe(1:1)@Fe WM. It contributed less active sites exposure in block-like structure than cubic structure. The Mn-Fe(1:2)@Fe WM exhibited the lowest catalytic activity and the most narrow temperature

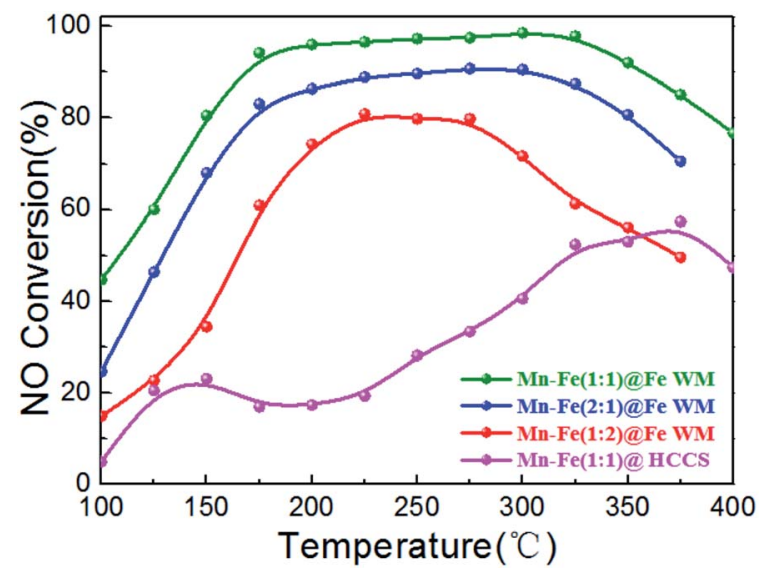

Fig. 6 Plots of NO conversion versus reaction temperature over $\mathrm{Mn}-$ FeaFe WM catalysts. Reaction conditions: $\left[\mathrm{NH}_{3}\right]=[\mathrm{NO}]=500 \mathrm{ppm}$, $\left[\mathrm{O}_{2}\right]=3$ vol\%, $\mathrm{N}_{2}$ as balance gas, GHSV $=20000 \mathrm{~h}^{-1}$. 
window than $\mathrm{Mn}-\mathrm{Fe}(1: 1) @ \mathrm{Fe} W \mathrm{WM}$ and $\mathrm{Mn}-\mathrm{Fe}(2: 1) @ \mathrm{Fe} \mathrm{WM}$, which only had near $75 \%$ NO conversion from $200-300{ }^{\circ} \mathrm{C}$. It was mainly due to the low content of $\mathrm{Mn}$ in the coating layer, which affected the catalytic activity. Moreover, $\operatorname{Mn}-\mathrm{Fe}(1: 1)$ (aHCCS showed a poor catalytic performance, which resulted in $\mathrm{Mn}-\mathrm{Fe}$ undesirable growth onto the honeycomb ceramics. This reflected the irreplaceable role of "twin iron source" in the process of crystal formation.

Furthermore, we studied the growth of $\mathrm{Mn}-\mathrm{Fe}$ on other common metal supports and tested the catalytic performance (Fig. S7†). The results showed that the catalytic activities of the other metal supports were significantly reduced (less than 60\%) under the same conditions, which was mainly attributed to the fact that the Mn-Fe species could not grow well on the surface. It reflected the irreplaceable role of "twin iron source" in the crystal growth process of heterogeneous nucleation and crystal growth process.

In actual working conditions, monolith catalysts should face a longer operation time and resist the adverse influences of water vapor on catalysts. ${ }^{48}$ Therefore, the stability and water resistance of the catalysts were investigated. The monolith catalysts were tested under the continuous running duration at $200{ }^{\circ} \mathrm{C}$ for $24 \mathrm{~h}$ (Fig. 7). In the whole reaction time, all of the catalysts kept a constant NO conversion. This result suggested the considerable stability of the catalysts, which could be related to the good catalytic stability of $\left(\mathrm{Mn}_{0.37} \mathrm{Fe}_{0.63}\right)_{2} \mathrm{O}_{3}$ and adhesion between the Mn-Fe bi-metal oxides and Fe wire mesh arising from the in situ growth and calcination procedure. The $\mathrm{H}_{2} \mathrm{O}$ tolerance was also tested under the same reaction temperature (Fig. 7, inset). As clearly shown, the addition of $10 \% \mathrm{H}_{2} \mathrm{O}$ could barely affect the De$\mathrm{NO}_{x}$ activities of the catalysts during the $8 \mathrm{~h}$ testing period. It was well documented that the inhibition effect of $\mathrm{H}_{2} \mathrm{O}$ did not affect the adsorption of $\mathrm{NH}_{3}$ molecules on the catalyst surface.

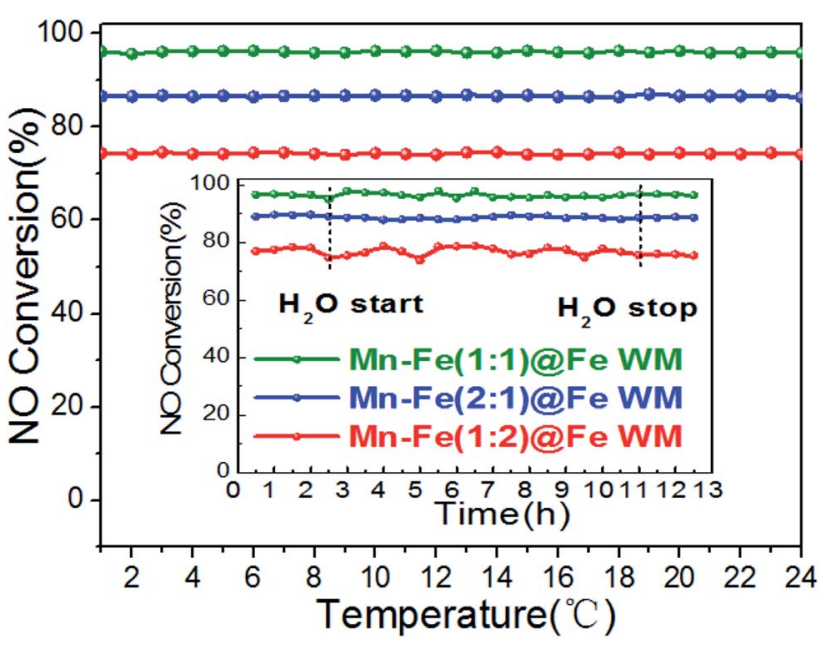

Fig. 7 Plots of stability and $\mathrm{H}_{2} \mathrm{O}$ tolerance (inset) of the $\mathrm{Mn}-\mathrm{Fe}(\mathrm{Fe}$ WM monolith catalysts. Reaction conditions: reaction temperature $=$ $200^{\circ} \mathrm{C},\left[\mathrm{NH}_{3}\right]=[\mathrm{NO}]=500 \mathrm{ppm},\left[\mathrm{O}_{2}\right]=3 \mathrm{vol} \%,\left[\mathrm{H}_{2} \mathrm{O}\right]=10 \mathrm{vol} \%$ (when used), $\mathrm{N}_{2}$ as balance gas, GHSV $=20000 \mathrm{~h}^{-1}$.
In order to understand the role of the active species, single Fe or Mn species monolithic catalysts (Mn@Fe WM and Fe@Fe WM) were prepared by deposition of single manganese or iron species on Fe wire mesh and the catalytic properties were studied. The results were shown in Fig. 8. There were less $40 \%$ of the NO conversion of Mn@Fe WM and less 80\% of Fe@Fe WM. The results showed that the growth of single manganese or iron on the Fe wire mesh cannot bring high catalytic activity as Mn-Fe@Fe WM monolith catalysts. For Fe@Fe WM, because the catalytic process only contained Fe species, the catalytic activity was not high. But for Mn@Fe WM, it was mainly due to the poor growth of pure Mn species on the Fe wire mesh, which resulted in a low $\mathrm{NO}$ conversion. It proved that $\left(\mathrm{Mn}_{0.37} \mathrm{Fe}_{0.63}\right)_{2} \mathrm{O}_{3}$ might be the main active species in the $\mathrm{NH}_{3}$-SCR reaction.

The catalyst was always deactivated due to the abundant alkali and alkaline earth metal ions contained in stack gases. ${ }^{49}$ The catalytic performance of Mn-Fe@Fe WM monolith catalysts for alkali resistance and regeneration were shown in Fig. 9. As shown clearly, though poisoned by $\mathrm{K}^{+}$with $0.3 \mathrm{wt} \%$ of the total mass of the monolith catalysts, the results indicated that the catalytic activity of three catalysts decreased obviously after alkali metal poisoning. The highest catalytic activities of $\mathrm{K}$ poisoning-Mn-Fe(1 : 1)@Fe WM, K-poisoning-Mn-Fe(2 : 1)@Fe $\mathrm{WM}$ and K-poisoning-Mn-Fe(1:2)@Fe WM of catalysts still achieved about $50 \%$ with temperature range of $225-400{ }^{\circ} \mathrm{C}$, 225-350 ${ }^{\circ} \mathrm{C}$ and $300-400{ }^{\circ} \mathrm{C}$, respectively. It showed that these monolith catalysts present good alkali resistance properties. After water washing the poisoned catalysts, the three catalysts showed excellent activity recovery. Especially for the Kpoisoning-Mn-Fe(1:1)@Fe WM, the catalyst activity achieved above $85 \%$ at $225{ }^{\circ} \mathrm{C}$. It can be attributed to the stable $\mathrm{Mn}-\mathrm{Fe}$ bimetal oxides structure and strong synergistic effect between the support and active species. The simple and good regeneration performance ensure that the catalyst could be used repeatedly, which effectively improves the utilization efficiency of the catalysts.

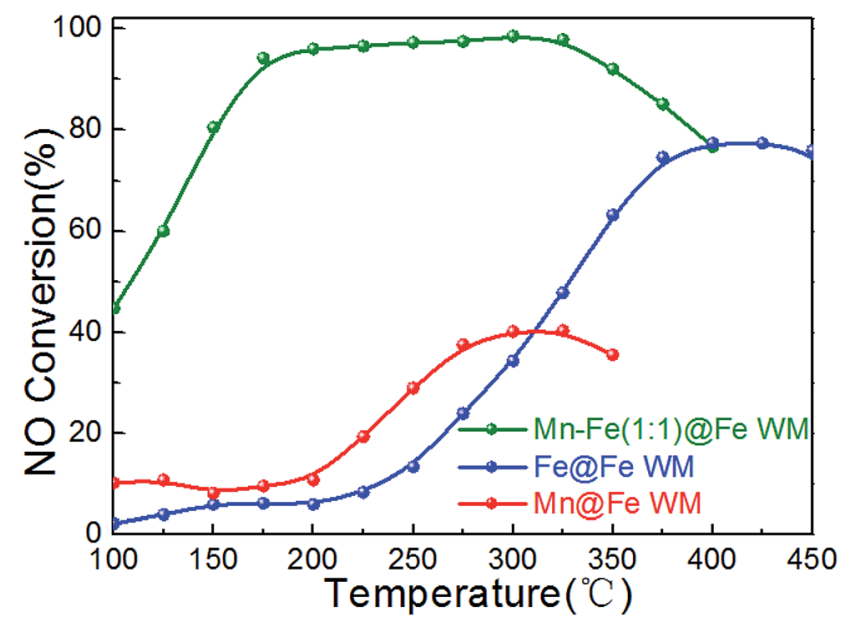

Fig. 8 Plots of NO conversion versus reaction temperature over $\mathrm{Mn}-$ FeaFe WM catalysts. Reaction conditions: $\left[\mathrm{NH}_{3}\right]=[\mathrm{NO}]=500 \mathrm{ppm}$, $\left[\mathrm{O}_{2}\right]=3$ vol\%, $\mathrm{N}_{2}$ as balance gas, GHSV $=20000 \mathrm{~h}^{-1}$. 


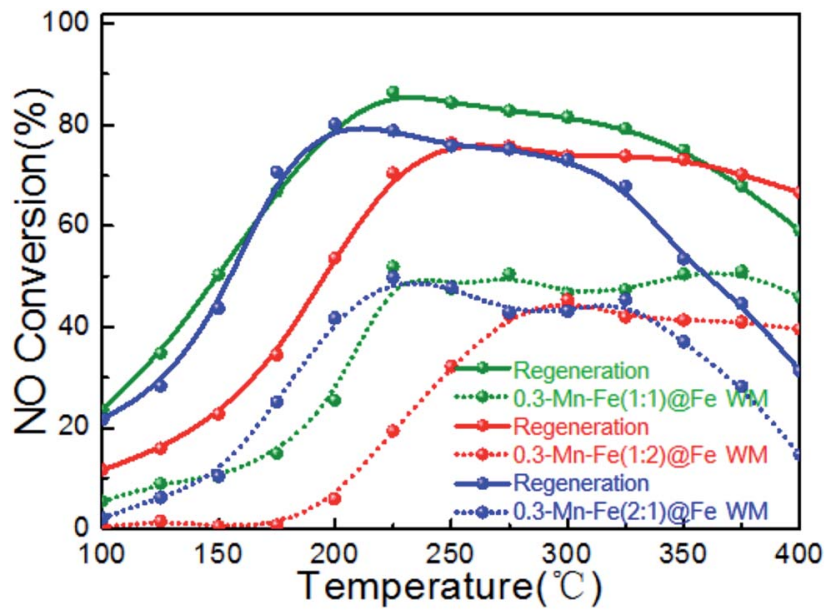

Fig. 9 Plots of alkaline tolerance and regeneration properties of $\mathrm{Mn}-$ FeaFe WM catalysts. Reaction conditions: $\left[\mathrm{NH}_{3}\right]=[\mathrm{NO}]=500 \mathrm{ppm}$, $\left[\mathrm{O}_{2}\right]=3$ vol\%, $\mathrm{N}_{2}$ as balance gas, GHSV $=20000 \mathrm{~h}^{-1}$.

\section{Conclusions}

In this work, we applied a "twin iron source" growth method for the in situ construction of Mn-Fe bi-metal oxides on the Fe wire mesh and used in $\mathrm{NH}_{3}$-SCR of NO. The results suggest that the cube-like structure on the surface of Fe wire mesh performed above $90 \%$ catalytic activity at $175-300{ }^{\circ} \mathrm{C}$. It is mainly attributed to the enhancement of reducibility and adsorption behaviors of $\left(\mathrm{Mn}_{0.37} \mathrm{Fe}_{0.63}\right)_{2} \mathrm{O}_{3}$, which was favorable for the catalytic process. In addition, the catalyst showed good stability and $\mathrm{H}_{2} \mathrm{O}$ tolerance. It was related to the good adhesion between the Mn-Fe bi-metal oxides and Fe wire mesh and the competitive adsorption of $\mathrm{NH}_{3}$ on the surfaces of the MnFe@Fe WM monolith catalysts. Moreover, the $\mathrm{Mn}-\mathrm{Fe}(1: 1)$ (aFe WM catalyst showed the best resistance to $\mathrm{K}^{+}$poisoning and the best regeneration performance. It was mainly because the structural stability of spinel structure of $\left(\mathrm{Mn}_{0.37} \mathrm{~F}_{0.63}\right)_{2} \mathrm{O}_{3}$ and strong synergistic effect between the support and active species. This simple in situ technique can not only obtain the catalyst directly, but also avoid the use of vanadium harmful to the environment and human health. This new kind of monolithic catalysts prepared by an in situ technique can be used as a potential substitute for vanadium based ceramic catalysts.

\section{Conflicts of interest}

There are no conflicts of interest to declare.

\section{Acknowledgements}

The authors acknowledge the support of the National Natural Science Foundation of China (U1462110). P. M. would like to thank the National Natural Science Foundation of China for International Young Scientists FY 2016 (21650110450).

\section{References}

1 P. Forzatti, I. Nova and E. Tronconi, Angew. Chem., 2009, 48, 8366-8368.

2 S. Beirle, K. F. Boersma, U. Platt, M. G. Lawrence and T. Wagner, Science, 2011, 333, 1737-1739.

3 K. A. Lomachenko, E. Borfecchia, C. Negri, G. Berlier, C. Lamberti, P. Beato, H. Falsig and S. Bordiga, J. Am. Chem. Soc., 2016, 138, 12025-12028.

4 P. Granger and V. I. Parvulescu, Chem. Rev., 2011, 111, 31553207.

5 C. Paolucci, A. A. Verma, S. A. Bates, V. F. Kispersky, J. T. Miller, R. Gounder, W. N. Delgass, F. H. Ribeiro and W. F. Schneider, Angew. Chem., 2014, 53, 11828-11833.

6 P. Forzatti, I. Nova and E. Tronconi, Ind. Eng. Chem. Res., 2010, 49, 10386-10391.

7 W. Wang, G. McCool, N. Kapur, G. Yuan, B. Shan, M. Nguyen, U. M. Graham, B. H. Davis, G. Jacobs, K. Cho and X. Hao, Science, 2012, 337, 832-835.

8 X. Li, J. H. Li, Y. Peng, W. Z. Si, X. He and J. M. Hao, Environ. Sci. Technol., 2015, 49, 9971-9978.

9 P. G. W. A. Kompio, A. Brückner, F. Hipler, G. Auer, E. Löffler and W. Grünert, J. Catal., 2012, 286, 237-247.

10 P. Forzatti, I. Nova, E. Tronconi, A. Kustov and J. R. Thogersen, Catal. Today, 2012, 184, 153-159.

11 X. Q. Wang, A. J. Shi, Y. F. Duan, J. Wang and M. Q. Shen, Catal. Sci. Technol., 2012, 2, 1386-1395.

12 S. B. Kristensen, A. J. Kunov-Kruse, A. Riisager, S. B. Rasmussen and R. Fehrmann, J. Catal., 2011, 284, 6067.

13 J. P. Chen and R. T. Yang, J. Catal., 1990, 125, 411-420.

14 Y. J. Zheng, A. D. Jensen and J. E. Johnsson, Ind. Eng. Chem. Res., 2004, 43, 941-947.

15 H. Kamata, K. Takahashi and C. U. I. Odenbr, J. Mol. Catal. A: Chem., 1999, 139, 189-198.

16 C. Fang, D. S. Zhang, S. X. Cai, L. Zhang, L. Huang, H. R. Li, P. Maitarad, L. Y. Shi, R. H. Gao and J. P. Zhang, Nanoscale, 2013, 5, 9199-9207.

17 L. Wang, X. Cheng, Z. Wang, C. Ma and Y. Qin, Appl. Catal., $B, 2017,201,636-651$.

18 P. G. Smirniotis, D. A. Pena and B. S. Uphade, Angew. Chem., 2001, 40, 2479-2482.

19 D. M. Meng, W. C. Zhan, Y. Guo, Y. L. Guo, L. Wang and G. Z. Lu, ACS Catal., 2015, 5, 5973-5983.

20 Z. M. Liu, J. Z. Zhu, J. H. Li, L. L. Ma and S. I. Woo, ACS Appl. Mater. Interfaces, 2014, 6, 14500-14508.

21 L. Zhang, L. Shi, L. Huang, J. Zhang, R. Gao and D. Zhang, ACS Catal., 2014, 4, 1753-1763.

22 S. X. Cai, H. Hu, H. R. Li, L. Y. Shi and D. S. Zhang, Nanoscale, 2016, 8, 3588-3598.

23 Z. H. Chen, Q. Yang, H. Li, X. H. Li, L. F. Wang and S. C. Tsang, J. Catal., 2010, 276, 56-65.

24 F. F. Cao, J. H. Chen, C. L. Lyu, M. J. Ni, X. Gao and K. F. Cen, Catal. Sci. Technol., 2015, 5, 1267-1279.

25 M. Y. Qiu, S. H. Zhan, H. B. Yu, D. D. Zhu and S. Q. Wang, Nanoscale, 2015, 7, 2568-2577. 
26 S. X. Cai, J. Liu, K. W. Zha, H. R. Li, L. Y. Shi and D. S. Zhang, Nanoscale, 2017, 9, 5648-5657.

27 J. Xu, H. R. Li, Y. Liu, L. Huang, J. P. Zhang, L. Y. Shi and D. S. Zhang, RSC Adv., 2017, 7, 36319-36325.

28 Y. Li, Y. Wan, Y. P. Li, S. H. Zhan, Q. X. Guan and Y. Tian, ACS Appl. Mater. Interfaces, 2016, 8, 5224-5233.

29 L. J. Zhang, S. P. Cui, H. X. Guo, X. Y. Ma and X. G. Luo, J. Mater. Chem. A, 2014, 390, 14-21.

30 L. J. Yan, Y. Y. Liu, K. W. Zha, H. R. Li, L. Y. Shi and D. S. Zhang, ACS Appl. Mater. Interfaces, 2016, 8, 5224-5233.

31 Y. L. Ye, M. Jin and D. C. Wan, J. Mater. Chem. A, 2015, 3, 13519-13525.

32 A. V. Boix, S. G. Aspromonte and E. E. Miro, Appl. Catal., A, 2008, 341, 26-34.

33 H. R. Li, D. S. Zhang, P. Maitarad, L. Y. Shi, R. H. Gao, J. P. Zhang and W. G. Cao, Chem. Commun., 2012, 48, 10645-10647.

34 Y. Shu, T. Aikebaier, X. Quan, S. Chen and H. Yu, Appl. Catal., B, 2014, 150-151, 630-635.

35 A. Montebelli, C. G. Visconti, G. Groppi, E. Tronconi, C. Cristiani, C. Ferreira and S. Kohler, Catal. Sci. Technol., 2014, 4, 2846-2870.

36 Q. F. Zhang, X. P. Wu, G. F. Zhao, Y. K. Li, C. Z. Wang, Y. Liu, X. Q. Gong and Y. Lu, Chem. Commun., 2015, 51, 1261312616.

37 J. Han, J. Meeprasert, P. Maitarad, S. Nammuangruk, L. Y. Shi and D. S. Zhang, J. Phys. Chem. C, 2016, 120, 1523-1533.
38 L. Huang, X. Zhao, L. Zhang, L. Y. Shi, J. P. Zhang and D. S. Zhang, Nanoscale, 2015, 7, 2743-2749.

39 H. Sun, Y. B. Zhang, X. Quan, S. Chen, Z. P. Qu and Y. L. Zhou, Catal. Today, 2008, 139, 130-134.

40 Y. Liu, J. Xu, H. R. Li, S. X. Cai, H. Hu, C. Fang, L. Y. Shi and D. S. Zhang, J. Mater. Chem. A, 2015, 3, 11543-11553.

41 S. X. Cai, D. S. Zhang, L. Y. Shi, J. Xu, L. Zhang, L. Huang, H. R. Li and J. P. Zhang, Nanoscale, 2014, 6, 7346-7353.

42 H. L. Guo, G. S. Zhu, I. J. Hewitt and S. L. Qiu, J. Am. Chem. Soc., 2009, 131, 1646-1647.

43 T. Yu, T. Hao, D. Fan, J. Wang, M. Shen and W. Li, J. Phys. Chem. C, 2014, 118, 6565-6575.

44 J. H. Kwak, R. Tonkyn, D. Tran, D. Mei, S. J. Cho, L. Kovarik, J. H. Lee, C. H. F. Peden and J. Szanyi, ACS Catal., 2012, 2, 1432-1440.

45 F. D. Liu and H. He, J. Phys. Chem. C, 2010, 114, 1692916936.

46 W. X. Tang, X. F. Wu, S. Li, W. H. Li and Y. F. Chen, Catal. Commun., 2014, 56, 134-138.

47 M. H. Castaño, R. Molina and S. Moreno, Appl. Catal., A, 2015, 492, 48-59.

48 Z. G. Lei, B. Han, K. Yang and B. H. Chen, Chem. Eng. J., 2013, 215, 651-657.

49 L. Zheng, M. J. Zhou, Z. W. Huang, Y. X. Chen, J. Y. Gao, Z. Ma, J. M. Chen and X. F. Tang, Environ. Sci. Technol., 2016, 50, 11951-11956. 